\title{
Plausible Scenarios for Thai Energy Businesses in the Next 30 Years
}

\author{
N. Nakapreecha*, J. Pongthanaisawan and W. Wangjiraniran \\ Energy Research Institute, Chulalongkorn University, Bangkok, Thailand
}

The energy sector is currently facing different challenges. It is necessary for business leaders to understand the forthcoming changes that will affect their businesses in order to prepare themselves for any uncertainties and take advantage of new opportunities. This paper identifies changes that are expected to have an impact on Thailand's energy system in the next 30 years and explores plausible scenarios for Thailand's energy sector under such changes. The study starts with an examination of global and local circumstances. The examination pinpoints a focal issue as "to achieve sustainable development goals (SDG) by 2050". Then, STEEP analysis is implemented to identify business drivers in social (S), technological $(T)$, economical $(E)$, ecological $(E)$, and political $(P)$ aspects. Subsequently,

OPEN ACCESS

Edited by:

Jin Xuan,

Loughborough University,

United Kingdom

Reviewed by:

Godwin Norense

Osarumwense Asemota, University of Rwanda, Rwanda Xiangyun Gao,

China University of Geosciences,

China

*Correspondence:

N. Nakapreecha nitida.n@chula.ac.th

Specialty section: This article was submitted to Sustainable Energy

Systems and Policies,

a section of the journal Frontiers in Energy Research

Received: 03 August 2020 Accepted: 01 December 2020

Published: 09 February 2021

Citation:

Nakapreecha N, Pongthanaisawan $J$ and Wangjiraniran W (2021) Plausible Scenarios for Thai Energy Businesses in the Next 30 Years.

Front. Energy Res. 8:590932. doi: 10.3389/fenrg.2020.590932 consultations with stakeholders are arranged to finalize the critical uncertainties. Policy and technology are found to be two of the most powerful factors affecting energy business and are, therefore, used as fundamental frameworks for scenario development. Accordingly, four plausible scenarios are derived providing different possible prospects for Thailand's energy businesses. The findings can further be used in the analysis of national energy balance with detailed sector-by-sector projections. All of which will be beneficial in strategic energy planning at both the national and corporate level with a view to achieving the SDGs by 2050.

Keywords: energy business, sustainable development goal, energy disruption, STEEP analysis, carbon policies, energy challenges, plausible scenarios

\section{INTRODUCTION}

The energy sector is experiencing a series of changes. Such changes transform a stable and continual business environment into an uncertain and turbulent one. This poses great challenges to business investors in view of corporate strategic planning (Grant, 2003). It is important for business leaders to understand the forthcoming changes that will affect their businesses. Otherwise, they may have problems with adapting to those changes and will eventually have to pay a considerable price in terms of value destruction, lower profits, and decline in competitiveness. Several case studies have been observed.

In the 2000s, traditional utilities in Germany overlooked the potential of distributed photovoltaic (DPV) generation. Later in the early 2010 s, they lost $97 \%$ of their electricity generation market shares to private investors (Richter, 2013).

Moreover, recent studies of the International Energy Agency (IEA) show a fundamental shift away from fossil fuels to renewable energy in the thermal power sector. The trend was observed from the fall of the annual final investment decision (FID) for both coal and gas-fired plants during 2016-2018 (IEA, 2019a; IEA, 2019b; IEA, 2019c). The downturn in thermal power investment has seriously affected traditional thermal power producers. General Electric (GE), Siemens, and Toshiba 
dominate the sector. Nearly $74 \%$ of GE's market capitalization over 2016-2018 has collapsed from misreading the pace of the post-Paris energy transition (Buckley et al., 2019), resulting in the loss of about 12,000 jobs in the power division (Proctor, 2017). Likewise, Siemens had to spin off its power and gas division, while Toshiba had to reduce its coal-fired power business (IEA, 2019a; IEA, 2019b; IEA, 2019c).

On the other side, the changing context brings great business opportunities to those with agility to adapt to market and business environmental changes. As in the case of declining thermal power investment, some utilities have merged their supply-side business to cover distribution networks and retail in order to ensure their supply resilience, energy efficiency, and professional demand-side services. For example, Enel, one of the energy giants, acquired EnerNOC, a US-based leading provider of smart energy management services. This acquisition enables them to deliver superior energy services to their current and prospective clients (EnerNOC, 2017). Moreover, Enel acquired eMotorWerks, a provider of e-mobility solutions, to be able to provide grid balancing solutions and pave their way into the promising electric mobility market. According to the head of their Global eSolutions division, the acquisition fulfills their portfolio of grid flexibility services, which includes a demand response network, distributed energy management systems, and battery storage solutions (Enel, 2016).

The above case studies emphasize the fact that an organization needs to keep an eye on changing aspects-not just to survive, but to thrive in the business. The volatility of the business environment makes strategic planning more difficult (Grant, 2003). Thus, businesses need to use systematic strategic foresight rather than intuition or gut feeling. They need a tool that can provide various possible future situations (scenarios). Such scenarios will expand the executive vision beyond their experience and encourage creative thinking. As a result, the executive will be able to create more flexible strategies for their business.

In consideration of Thailand, the country needs energy to supply its domestic demand, which is inconsistent with economic development, population growth, and urban growth (Ministry of Energy, 2015a; Ministry of Energy, 2015b). Thus, Thailand has long given its priority to energy security. The statistical data show energy consumption increases every year with a high proportion of imported energy (Figure 1). The net import of commercial primary energy has accounted for more than $50 \%$ of the total supply since 1995. This proportion is anticipated to grow as the proven oil and gas reserves are depleting. This will affect not only energy security, but also the national energy expenditure (IRENA, 2017).

According to Figures $\mathbf{2}$ and 3, most commercial primary energy consumption and import are fossil-based. This results in the increase in environmental problems, especially the increase of greenhouse gas (GHG) emissions. Additionally, people have negative attitudes toward certain fossil fuels, especially coal. Protests against coal-fired power plants have been seen in the country (Heinrich-Böll-Stiftung, 2020). In response, Thailand has set a renewable energy goal of $30 \%$ of the total final energy consumption by 2036 in the Alternative Energy Development
Plan or AEDP 2015 with an intention to diversify energy sources as well as to decrease environmental pollutions (Ministry of Energy, 2015a; Ministry of Energy, 2015b).

In view of business players, Thai energy business is still centered around state-owned enterprises (SOEs). In the power sector, the Electricity Generating Authority of Thailand (EGAT) is a SOE responsible for generating, transmitting, and wholesaling electricity. In addition, there are two SOEs responsible for distributing and providing low-voltage electricity to end users. They are the Metropolitan Electricity Authority (MEA) and the Provincial Electricity Authority (PEA) (BOI, 2020). Although Thailand has encouraged private companies to enter the power generating sector as an independent power producer (IPP), a small power producer (SPP), and a very small power producer (VSPP) in the power generation sector; electricity produced by these private companies has to be sold to EGAT, PEA, and MEA (BOI, 2020). In the oil and gas sector, PTT public company limited, engages in the entire supply chain for oil and gas. Its businesses cover exploration, transmission, oil refinery and gas separation, and petrol stations. It is the sole buyer of oil and gas produced domestically and the sole operator of gas transmission and separation (Nikomborirak, 2017).

Considering the mentioned situations in Thailand, it can be anticipated that the Thailand energy system will soon be facing changing circumstances. Accordingly, it is important that Thailand develop scenarios to foresee possible situations in order to be able to adapt to the upcoming changes.

Scenario analysis is a tool to envisage possible future events by examining various influential variables and identifying critical uncertainties. Scenarios are not a future prediction, but rather a visualization of alternative views of the future in the context of different sets of key variables (Grant, 2003). This implies that scenarios are not limited to a single vision of the future, but they reveal a variety of possibilities. At the same time, they form a framework for describing pathways toward each vision and finding appropriate actions for each path (Schwartz, 1996).

With better understanding of future uncertainties, scenarios can reshape the framework people perceive in the future (Gilovich, 1981). And, as they reveal multiple possible future circumstances, scenarios have a significant role in designing flexible strategies, which foster alertness and responsiveness of decision makers to those changing circumstances (Grant, 2003). Unsurprisingly, several businesses have adopted scenario planning in their strategic planning to explore and exploit the world of great uncertainties.

Shell is one of the world's most well-known scenario developers. The company has been developing and deploying various scenarios since the 1970s to assist its executives in making decisions (Shell, 2020). In 1970, its scenarios illustrated the possibility of the oil price upsurge induced by the Organization of the Petroleum Exporting Countries (OPEC). Later in 1973, the oil prices actually quadrupled. Since then, Shell has been using scenario planning even more seriously to foresee and exploit succeeding oil price swings (Schoemaker, 1993). In addition, the company has developed various scenarios to identify emerging global challenges, which have helped them 


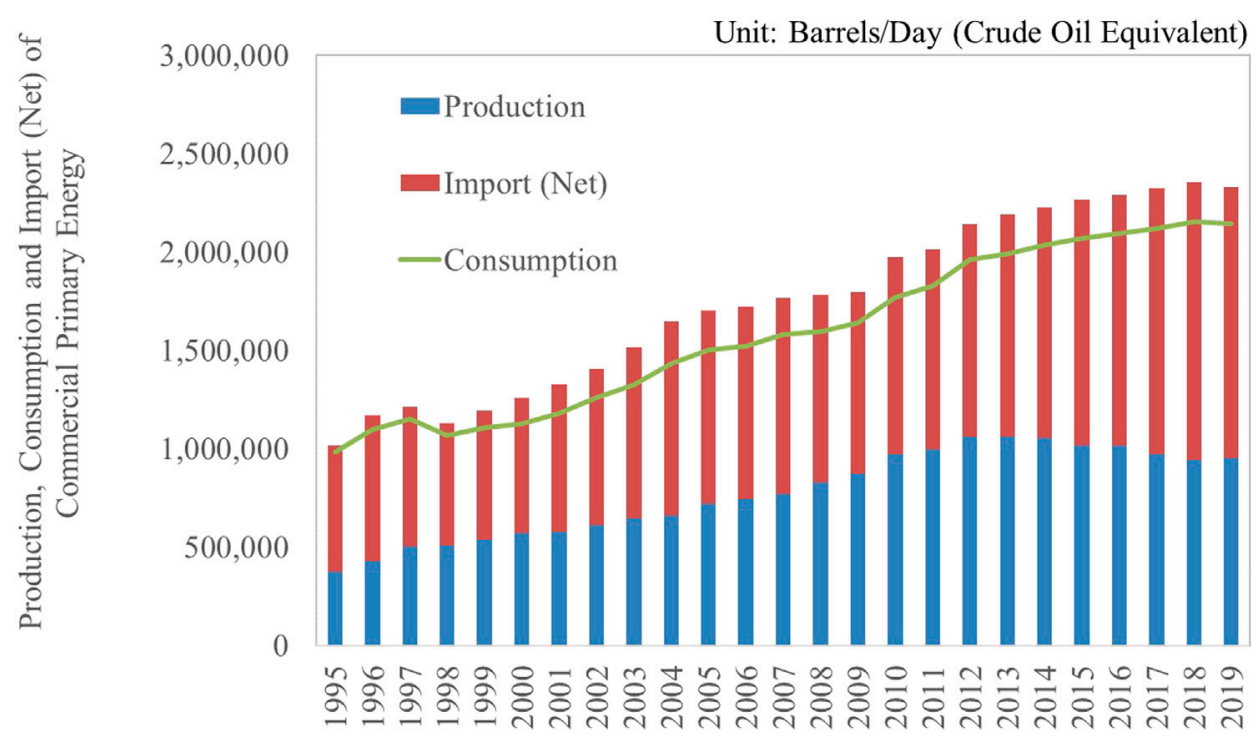

FIGURE 1 | Production, consumption, and import (net) of commercial primary energy (EPPO, 2020b).

make critical decisions in uncertain times and overcome energy and environmental challenges (Shell, 2020).

The world energy outlook developed by the IEA is one of the most recognized energy outlooks that provides comprehensive scenarios, which map out the results of various energy policies and investment decisions. Their 2019 issue illustrates a pathway that enables the world to achieve climate, energy access, and air quality targets while ensuring the reliability and affordability of energy for an increasing population (IEA, 2019a; IEA, 2019b; IEA, 2019c).

Although, there are a number of global energy scenarios publicly available to be used as guidelines for exploring the global energy outlook, the country still needs its own tailormade scenarios specially built upon its own context. Moreover, it is important for the country to explore more than one possible scenario to avoid rigid strategic planning. This is to ensure that the formulation of energy strategies and policies will be appropriately developed for that country and will be flexible to changes.

In view of Thailand, there are five energy master plans, namely 1) the Thailand Power Development Plan or PDP, 2) the Energy Efficiency Development Plan or EEDP, 3) the Alternative Energy Development Plan or AEDP, 4) the Natural Gas Supply Plan, and 5) the Petroleum Management Plan (EPPO, 2016). These plans can provide frameworks for business strategy development. However, under dynamic circumstances, any framework will be too rigid for businesses as well as for the country's energy security, if they want to develop strategies based on current plans without considering the upcoming changes.

This paper does not intend to indicate the future of energy business in Thailand. But it does intend to reveal changes that have an impact on Thailand's energy system in the next 30 years and explore plausible scenarios of Thailand's energy business under those changes. This paper is to provide a narrative explanation of how Thailand's energy business could look in the next 30 years. The result can be further used for the assessment of future energy demand and supply, and corresponding environmental impacts such as greenhouse emissions. All of which are essential to the formulation of effective energy strategies and policies at both corporate and national levels.

\section{METHODOLOGY}

This research consists of four steps: the identification of the focal issue, the identification of drives, the identification of critical uncertainties, and the development of plausible scenarios.

\section{Identification of Focal Issue}

All scenarios are developed based on the focal issue, which has critical consequences for the future of the organization (Garvin and Levesque, 2006). Thus, the first step is to identify the focal issue that an energy organization should focus on. For effective business strategic planning, the focal issue should have a long-term influence on the business and be aligned with global changes. Therefore, it is important to address both Thailand's issues as well as global trends and development, which will affect future patterns of energy supply and consumption. Consequently, consultation with stakeholders from the management level to practitioner level in a broad range of functions and divisions is arranged to finalize the focal issue. The timeframe, scope, and focal variable are defined in this step.

\section{Identification of Drivers}

At this step, key drivers that will significantly influence the focal issue are identified. A common tool used for assessing influential factors is STEEP analysis, which is applied here. The analysis provides an overview of current and future circumstances impacting the business 


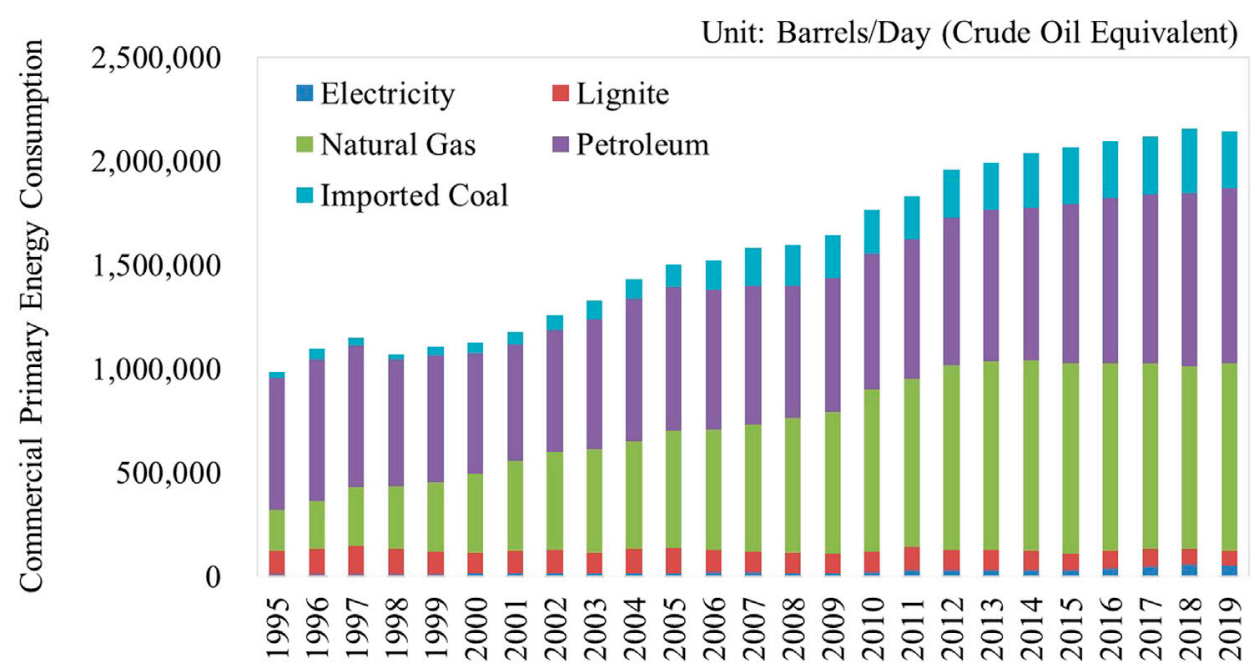

FIGURE 2 | Commercial primary energy consumption (EPPO, 2020b).

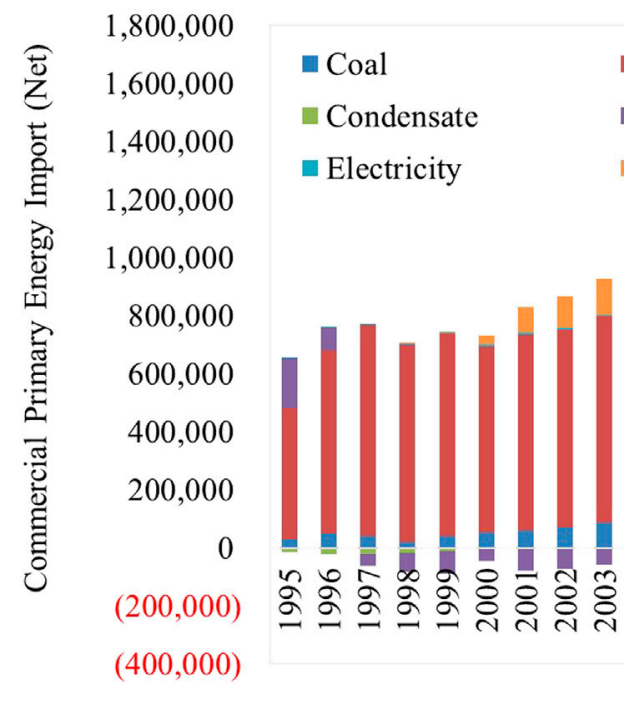

Unit: Barrels/Day (Crude Oil Equivalent)

- Crude Oil

- Petroleum Products

Natural Gas \& LNG

FIGURE 3 | Commercial primary energy import (net) (EPPO, 2020b).

in five areas: social, technological, economic, ecological, and political (PESTLEAnalysis.com, 2015). The framework of STEEP analysis is illustrated in Table 1. In the analysis, the issues and trends are mapped into the respective STEEP area to investigate how they affect the energy business.

It should be noted that not all the identified drivers are equally important or equally uncertain (European Foresight Platform, 2010). In addition, some drivers are predetermined, while some are uncertain. Thus, it will be helpful to identify the inevitable and necessary ones as well as the unforeseeable and essential ones (Schwartz, 1996). In this regard, further study on each driver is required to understand its essence and impact on the energy business.

\section{Identification of Critical Uncertainties}

In order to examine the influential drivers in detail, a workshop with stakeholders is organized to evaluate those drivers based on two criteria: 1) the degree of importance for the success of the focal issue and 2) the degree of uncertainty underlying in those drivers (Schwartz, 1996). Consequently, the drivers are categorized into four groups (Figure 4).

- Group 1: The small significance (low importance, low uncertainty) group is usually considered as insignificant to the scenario development and may be disregarded.

- Group 2: The revisit (low importance, high uncertainty) group is the group that should be revisited periodically as its high uncertainty may alter its importance over time. 
TABLE 1 | Framework of STEEP analysis (PESTLEAnalysis.com, 2015).

\begin{tabular}{|c|c|c|c|c|}
\hline Social & Technological & Economic & Ecological & Political \\
\hline $\begin{array}{l}\text { Social changes, e.g., demo- } \\
\text { graphic change, behavioral } \\
\text { changes, and lifestyle } \\
\text { changes }\end{array}$ & $\begin{array}{l}\text { Technological advancement and } \\
\text { convergence, e.g., innovations } \\
\text { and trends in product } \\
\text { development }\end{array}$ & $\begin{array}{l}\text { Changes in economic context, } \\
\text { e.g., domestic economic growth, } \\
\text { interest, income, profit, and mar- } \\
\text { ket competition }\end{array}$ & $\begin{array}{l}\text { Ecological impacts of prod- } \\
\text { ucts and/or services in } \\
\text { both physical and biologi- } \\
\text { cal terms }\end{array}$ & $\begin{array}{l}\text { Political changes affecting laws, reg- } \\
\text { ulations, and policies, e.g., the na- } \\
\text { tional development plan, national } \\
\text { energy plans }{ }^{\text {a }} \text {, incentives for busi- } \\
\text { nesses, as well as regulatory bur- } \\
\text { dens for businesses }\end{array}$ \\
\hline
\end{tabular}

aThese include: (1) the Thailand Power Development Plan or PDP, (2) the Energy Efficiency Development Plan or EEDP, (3) the Alternative Energy Development Plan or AEDP, (4) the Natural Gas Supply Plan, and (5) the Petroleum Management Plan.

\begin{tabular}{|c|c|c|}
\hline \multirow{2}{*}{ 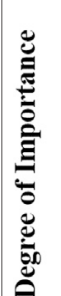 } & $\begin{array}{c}\text { Group } 3 \\
\text { The Importance }\end{array}$ & $\begin{array}{c}\text { Group } 4 \\
\text { The Critical Uncertainty }\end{array}$ \\
\hline & $\begin{array}{l}\text { Group 1 } \\
\text { The Small Significance }\end{array}$ & $\begin{array}{c}\text { Group } 2 \\
\text { The Revisit }\end{array}$ \\
\hline
\end{tabular}

Degree of Uncertainty

FIGURE 4 | Importance-uncertainty matrix (Rialland and Wold, 2020).

- Group 3: The importance (high importance, low uncertainty) group should be addressed in all scenarios, owing to its high impact.

- Group 4: The critical uncertainty (high importance, high uncertainty) group is the most critical driver in developing scenario logic and defining plausible scenarios.

The main purpose of this step is to identify the critical uncertainties as they are considered to have a critical role in determining Thai energy scenarios. However, it should be noted that the real situation may be different from the developed scenarios. Nevertheless, it will encompass elements of the scenarios. Thus, a good scenario should identify most of the plausible futures. In addition to the key drivers, some other drivers with less importance and uncertainty should be integrated in the scenario building. They may be served as reference points, signal posts, narrative components, or minor details, which add more clarity to the scenarios (Rialland and Wold, 2020).

\section{Development of Plausible Scenarios}

The $2 \times 2$ matrix technique (Rhydderch, 2017) is employed in developing scenarios in this study. In this regard, two of the critical uncertainties with greatest importance and uncertainty are selected to be used as fundamental axes of a scenario matrix. Determining these axes is one of the most important steps in the process of scenario development as it is necessary to ensure that the four generated scenarios are clearly differentiated and that their contrasts make a difference for decision making (Schwartz, 1996; Rhydderch, 2017). It is this step where intuition, insights, and imagination play the biggest part (European Foresight
Platform, 2010). Subsequently, the scenario narratives are accordingly developed by applying other previously identified drivers.

\section{RESULTS AND DISCUSSION}

\section{Identification of Focal Issue Global Situation and Challenge}

According to this review, the environment and digitalization are playing a leading role in the growth of global economic and energy businesses (World Economic Forum, 2019). With the rise of environmental concerns, both of them have widely been integrated into economic and energy policies. The 3D's (decarbonization, decentralization, and digitalization) have become even more prominent in shaping the directions of businesses, and national and global policies (Silvestre et al., 2018). Modern technologies and innovations are encouraged to be more and more environmentally friendly (Tundele, 2015).

In addition, it is observed that the trend of energy demand will shift toward low-carbon options (Figure 5). Demand for renewable energy is expected to have the greatest growth rate making the renewables one of the world's major energy sources over the next 10-20 years. In contrast, there is likely to be a downturn in the use of fossil-based fuels. Although it is forecasted that natural gas consumption will remain in the future, oil and coal consumptions are expected to decline dramatically, particularly in advanced economic countries. Their growth will be seen only in the emerging markets.

The above observation indicates the increase of environmental awareness globally. However, the most concrete movement toward showing that the world wants to take environmental issues seriously is the establishment of sustainable development goals (SDGs).

Adopted by all United Nations Member States in 2015, the SDGs are recognized as a global call for action to eradicate poverty, protect the Earth, and ensure peace and prosperity for everyone by 2030 (UNDP, 2020). Emphasizing the importance of these global goals, the IEA has proposed the sustainable development scenario (SDS) that maps out a way to meet sustainable energy goals across all parts of the energy system (IEA, 2019a; IEA, 2019b; IEA, 2019c). Moreover, Shell's Sky scenario illustrates a pathway to achieve the Paris Agreement target. It reveals the potential to evolve the energy system to meet 


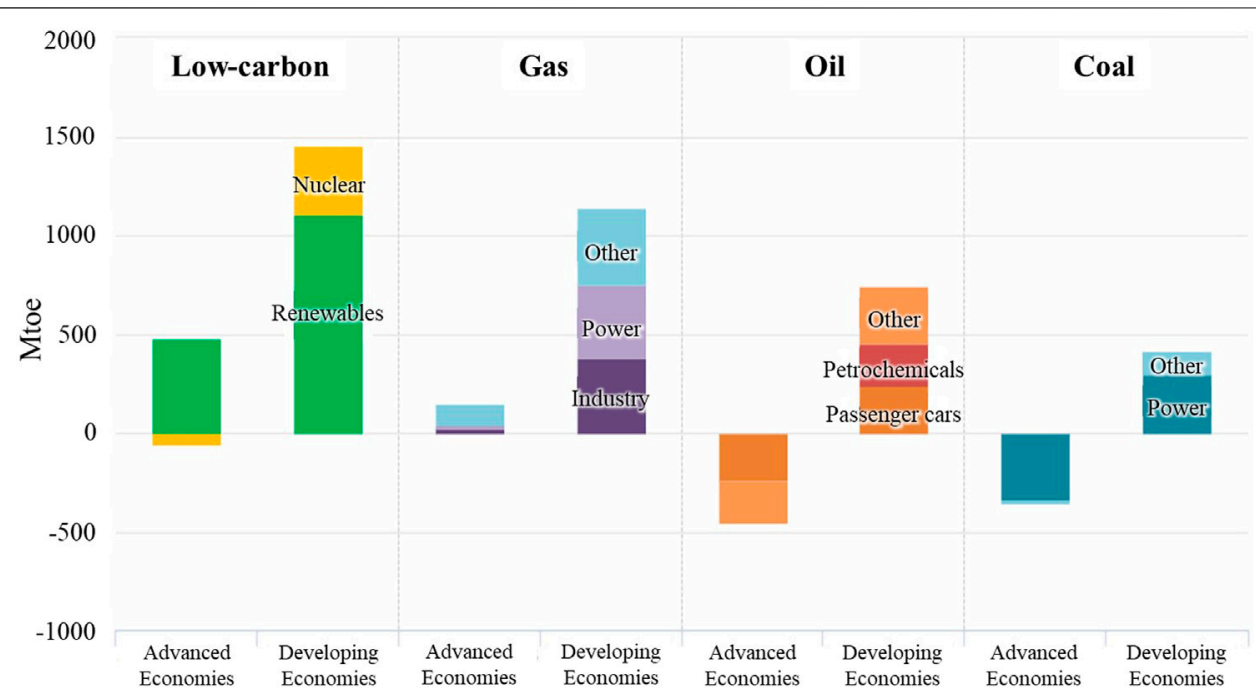

FIGURE $\mathbf{5}$ | Change in total primary energy demand, 2017-40 in the new policies scenario (NPS) (IEA 2018).

global energy demand without delivering a climate burden to future generations (Shell International BV, 2018).

\section{Challenges for Thailand}

Thailand is currently confronting several challenges impeding national development ranging from economic, social, and environmental challenges (National Strategy Secretariat Office, 2018). On the economic side, the economic structure has not yet been completely driven by innovative technology. While approximately $30 \%$ of the total labor force are in the agricultural sector (National Statistical Office, 2019), productivity in the sector is still relatively low. Furthermore, Thai workforces do not yet meet expected requirements and demands of the labor market. Unavoidably, poverty and income inequity remain the long-term concerns on the social side (National Strategy Secretariat Office, 2018). In addition to economic restructuring, the country will need to stimulate new businesses that create higher values in order to improve national competitiveness, economic growth, and income distribution. Energy security and stability are needed to support these needs.

Environmental issues have been long-term problems in Thailand (Panya and Sirisai, 2003). Air emissions are among the most concerning problems (Narita et al., 2019). Carbon emissions from energy consumption are on the rise in major sectors, i.e., power generation, transport, and industry (Figure 6). Thanks to national commitments to major international agreements, substantial action plans have been developed to tackle certain issues. Such commitments include the greenhouse gas reduction goals under the United Nations Framework Convention on Climate Change (UNFCC) and the sulfur limit for marine fuel oil set by the International Maritime Organization (IMO) (MNRE, 2015; ONEP, 2015; Thai Oil, 2020). However, local air pollution issues such as fine particulate matter $\left(\mathrm{PM}_{2.5}\right)$ are still waiting for serious and long-term solutions (Khidhir, 2020).
Thailand is expected to face the challenges of disruptive technologies (TDRI, 2018). More importantly, the adoption of such technologies is anticipated to affect the overall energy consumption pattern. Electric vehicles (EV) can be viewed as an example. Previous study shows that EV users tend to recharge their vehicles at night (Pasaoglu et al., 2013). As a result, night time load will increase. This is also in line in case of solar PV (Hudson and Heilscher, 2012). Therefore, there is a chance that peak demand will be shifted from day to night with the growth of EV users and solar PV users. Preparations must be in place to cope with the demand shift, such as demand response programs, to avoid an energy supply shortage.

The above findings suggest that, in the next phase of national development, Thailand needs to give priority to environmental protection in parallel with economic growth. As uninterrupted energy supply is the backbone of economic development, the energy sector has to put a great deal of effort into delivering reliable energy to those who need it without leaving environmental burden to the world. Accordingly, the focal issue that Thai energy businesses should focus on is "to achieve sustainable development goals (SDG) by 2050".

\section{Identification of Drivers}

Based on the STEEP analysis, factors which drive Thailand's energy system toward SDG are described as follows.

\section{Social Factors}

The shift in the lifestyle of Thai people toward a more urban and sharing economy is the first social factor identified for their influence on the future of energy businesses. Mobility-as-aservice is expected to become more popular as it offers more transport options, from buses to cars and bicycles (Sutthasri et al., 2019). The advancement and convergence of digital technology will enhance the efficiency of digital tools to facilitate the provision of this service. In addition, e-commerce is becoming 


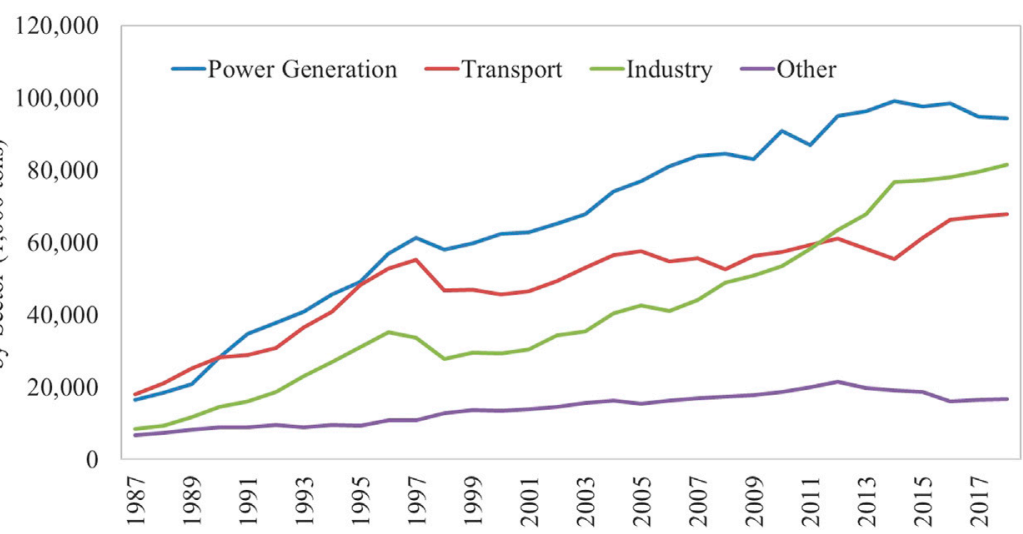

FIGURE 6 | $\mathrm{CO}_{2}$ emissions from energy consumption by sector (EPPO, 2020a).

even more popular as people prefer to use electronic financial transactions through their personal gadgets (Rastogi, 2018).

As people continue to migrate to metropolitan areas, a rise in population density is anticipated in certain areas, even though the overall population growth rate is decreasing (Vapattanawong and Prasartkul, 2005). Aging society is another area that should be taken into consideration. Thailand expects to become a fully aging society by 2021 with the population over 60 years of age accounting for more than $20 \%$ of the total population (Department of Elderly Affairs, 2019). This results in a reduction in the overall number of laborers and changes consumer behavior. Both of which will have a negative impact on national economic development.

And lastly, a shift towards urbanization is anticipated. City development will be based on transit-oriented development (TOD) such as trains and electric trains. Such developments will offer mobility advantages and flexibility as well as minimize reliance on personal vehicles (Nakamura et al., 2016). Vertical living, particularly in the vicinity of public transport, will be increased (JICA, IDCJ, Pacet, 2013).

\section{Technological Factors}

The first technology factor expected to have an impact on Thailand's energy business is efficiency-enhancing technology, such as energy efficiency, product efficiency, production efficiency, and transport efficiency. It also covers zero energy designs and architecture (Ministry of Energy, 2011).

Digital and information technology is most likely to increase its role in the energy business. With the ability to provide prompt and accurate responses, it is expected that this technology will be widely deployed in resource management systems, such as smart grids, smart cities, and smart farming. All of which will lead to greater energy and environmental conservation (IEA, 2017; Virk et al., 2020). Furthermore, the technology will also help improve people's quality of life. For example, high-speed internet and internet of things (IOT), which interconnects devices, provide an easy way for users to access, control, and operate electric devices over the internet (Atkinson and Castro, 2008; Farooq et al., 2015). In addition, the digital and information technology will empower online market platforms as it enables safer and more efficient online transactions (Qin et al., 2009).

The evolution of renewable and alternative energy technology has improved production efficiency and has significantly driven down the cost of renewable and alternative energy (IRENA, 2020a; IRENA, 2020b). Consequently, this will improve the price competitiveness of green energy against fossil fuels. And when combined with the higher efficient energy storage systems, the demand for renewable and alternative energy is expected to increase (IEA, 2011).

Likewise, the technology of electric and autonomous vehicles has been greatly developed so that major limitations are being eradicated and vehicle prices are being substantially reduced (Seba, 2014). With a solid plan on the development of charging infrastructures (EGAT, PEA, MEA, 2016), it is expected that the demand for electric and autonomous vehicles in Thailand will be increased. Additionally, high-speed trains are also expected to have a larger role in the future (Ministry of Transport, 2017). Robotics, artificial intelligence, and advanced materials are also marked as important in the development of energy systems (Perez et al., 2017; ACerS, AIST, ASM, MRS, TMS, 2010).

\section{Economic Factors}

Numerous economic factors are identified for their potential impact on the energy business. National economic growth is one major influential factor as it obviously reflects national demand for energy and resources (Yeager et al., 2012). Certain Thailand policies aiming to stimulate the domestic income, trading power, and growth of industrial and service sectors (National Strategy Secretariat Office, 2018) are also expected to affect total energy demand.

Different economic and industrial structures entail different energy intensity and energy consumption patterns. A heavy industry-based economy, which is generally highly resource intensive, will face an increase in energy consumption at an accelerated rate. On the contrary, an economy that is driven by high value-added industries and services normally consumes comparatively fewer resources (ERI, 2020). Thus, a country 
with this kind of economy and industrial structure will have greater overall energy efficiency.

Energy prices in global markets will continue to be a key consideration for consumers in energy and technology selection as it is often seen that the markets quickly respond to price changes. In addition, the role of geopolitics as a main driver behind oil price changes is expected to be lessened, while unconventional energy is increasing its influence on the energy market (Neville et al., 2017).

International economic cooperation provides options for international energy trading and energy security strengthening (Liu et al., 2019). Such cooperation includes the Association of Southeast Asian Nations (ASEAN), the framework of cooperation between ASEAN and the negotiating countries (ASEAN Plus), and the Economic Cooperation Development Program in the Greater Mekong Sub-regional (GMS).

Mega projects usually provoke energy demand in various forms as they entail the establishment of new industrial estates and the development of a more connected transportation network.

Various sustainability concepts such as circular economy, bioeconomy, and sufficiency economy philosophy, are expected to have impacts on the energy system. Described as an economy with a closed-resource loop (Wautelet, 2018), a circular economy encourages the rematerialization and reuse of waste with the aim to decouple economic growth from finite resource use (Ellen Macarthur Foundation, 2017). In other words, a circular economy will be a key mechanism to promote waste utilization including waste-to-energy. This will affect the demand for virgin materials as well as production and consumption patterns (Rizos et al., 2017).

Bio-economy is expected to give a positive impact on the development of bio-energy. This is particularly for the use of agriculture and residual waste as energy. According to its purpose to promote self-sufficiency (The Chaipattana Foundation, 2017), the philosophy of sufficiency economy can be applied in the transition of energy consumers to energy prosumers.

The last factor that is expected to have an impact on the energy business is economic crisis. Economic crisis is an event that is unlikely to occur but it will have an enormous impact on both the economy and energy sector. The mid-1997 crisis plunged Thailand's GDP growth to its lowest point since 1960 (Figure 7). The country's external debt reached more than $\$ 70$ billion or about $38 \%$ of the GDP (Hewison, 1999). And as a net energy importer, the increase of oil price, together with the increase of interest rates on debt from past infrastructure borrowing, put a heavy burden on the country (Julian, 2000). The economic stagnation shrunk the total energy demand and hampered new energy development projects as well as facility construction projects (Nakano and Honda, 2000). The government finally decided to privatize the energy industry and make institutional arrangements with an objective to improve overall performance (Chaivongvilan et al., 2008). In addition, it is expected that the economic crisis may have had a negative impact on renewable projects as the country may have had to turn to cheaper energies, such as coal for their cost minimization (Nakano and Honda, 2000).

\section{Ecological Factors}

The climate change agreement is an important mechanism for the continuous growth of the renewable energy market (IRENA, 2017). The commitment on greenhouse gas (GHG) emissions requires mitigation measures at a global scale. Common measures include enhancing energy efficiency and fostering the use of renewable energy (IRENA, 2017). Additionally, carbon pricing instruments, e.g., cap-and-trade and carbon tax, are also important drivers for GHG emission mitigation. As the carbon pricing may have adverse effects on carbon intensive industries (Kojima and Asakawa, 2016), careful policy formulation is required to balance the effort to reduce GHG emissions and mitigate negative effects of the instruments.

Local air pollution issues such as fine particulate matter $\left(\mathrm{PM}_{2.5}\right)$ and nitrogen oxides (NOx) have become one of the most critical issues in Thailand during the past few years (Narita et al., 2019). With the concern over their adverse health effects, public awareness of pollution reduction has been dramatically raised. The need to reduce such pollutants stimulates the consumption of low-carbon fuels and renewable energy in the power, industry, and transport sectors (Narita et al., 2019).

As the positive attitude of consumers toward green products and services are expected to be increased, producers and service providers need to pay more attention to the life cycle assessment. This also encourages organizations and business enterprises to improve their corporate carbon footprint (Thongplew et al. 2017).

Domestic reserves of natural resources, which include crude oil, natural gas, coal as well as renewable energy potential, are important considerations in the development of policies concerning energy usage in each sector. For example, the decline of domestic natural gas reserves has led to a shift in the power sector fuel mix toward more fuel diversification with a smaller natural gas proportion (Ministry of Energy, 2015a; Ministry of Energy, 2015b). In addition, based on the fact that the Thai agricultural sector has high potential for renewable energy, the government has set the challenging target for biogas and biomass development (Suthiwong, 2017).

\section{Political Factors}

Several policies are considered to have potential impacts on the energy system of Thailand. The first one is legislation to promote renewable energy at a national level. The economics of renewable energy are typically not competitive compared to that of fossil fuels (Griffith-Jones et al., 2011). Moreover, renewable energy does not have prolonged government subsidies, unlike fossil fuels. This means that renewable energy is more expensive and makes it more difficult for renewable energy to penetrate the market (ERI, 2015). Thus, supporting legislation is needed to boost the market for renewable energy at the early stage when its price is still comparatively high. An example of such policies are feed-in tariffs and biofuel mandates (NESDB, 2011).

Mandatory measures are effective tools to achieve desired outcomes. Current mandatory measures in the Thai energy sector involve energy performance control, such as the requirement of an energy conservation plan in designed buildings and designated factories, and the implementation of 
GDP Growth (Annual \%)

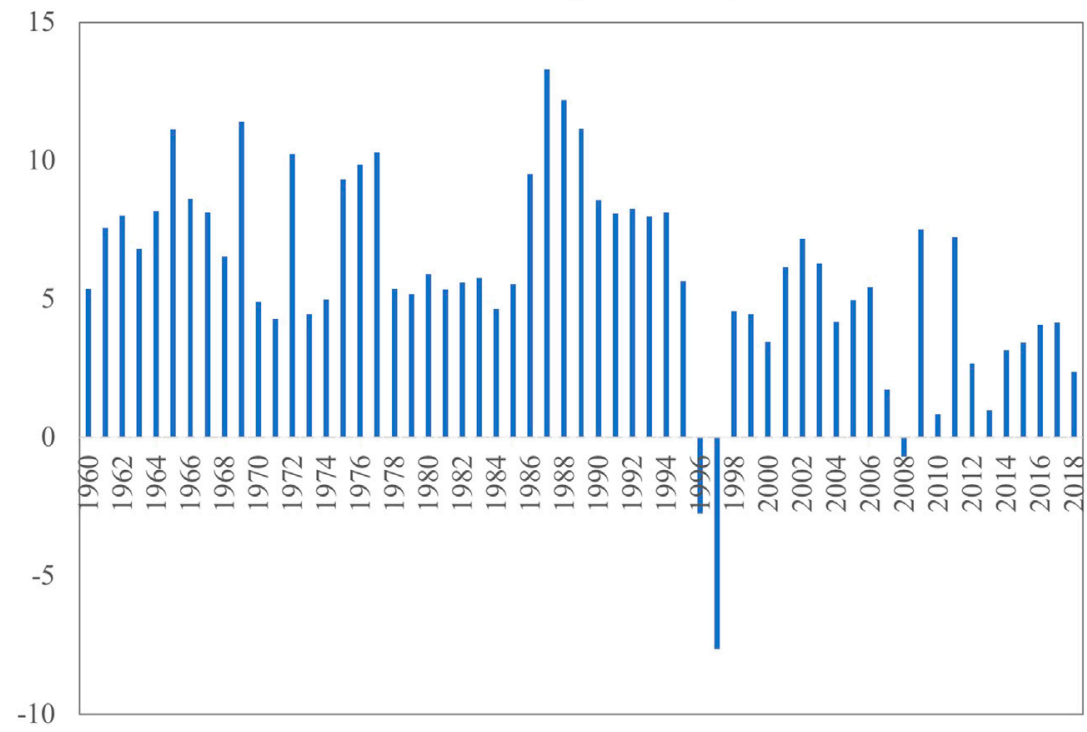

FIGURE 7 | Thailand GDP growth (World Bank, 2019).

a building energy code for buildings with a total area equal to 2,000 square meters or more (Office of the Council of State, 2007; Government Gazette, 2009). In addition to Thai measures, some international regulations also have an impact on energy businesses in Thailand. An example of an international regulation is the International Maritime Organization (IMO) regulation, which limits sulphur content in marine fuel oil at $0.5 \%$ mass by mass for vessels operating outside Emission Control Areas (ECAs) and at $0.1 \%$ mass by mass for vessels operating within ECAs (EIA, 2019).

Policies concerning the development of an energy business structure and governance have impacts on the development of energy efficiency, the determination of fuel type, and the growth of renewable energy (ERC, 2018). Moving toward a competitive industrial structure with the use of advanced trading platforms will optimize fuel selection. In addition, realizing the benefits of liberalization in the energy sector, Thailand has promoted competition in the oil business, while also beginning to allow third-party access to pipeline infrastructure and LNG terminals in the natural gas business (ERC, 2018).

To encourage self-dependency in the digital age, decentralization policies support power development for selfconsumption and peer-to-peer trading (IRENA, 2020a; IRENA, 2020b). It is expected that there will be local power development across the country as well as central infrastructure for inter-region power management (Ministry of Energy, 2018). In addition, according to the Power Development Plan 2018 (PDP2018), Thailand began to assess regional power demand and supply as part of the feasibility study on decentralization system development. Moreover, there are various pilot plants supporting decentralization, such as the smart grid pilot project in Mae Hong Son Province (EGAT, 2018) and the solar roof power generation project (Energy Regulatory Commission, 2016).
Energy pricing policies are one of the tools that government uses to set the direction of energy development. They have been used to stimulate markets for renewable energy as well as other energy. Previous pricing policies include price fixing policies for natural gas vehicles (NGV), adder and feed-intariff policies for renewable energy, and price subsidy policies for biofuels. Energy pricing policies are expected to become even more important, especially those that dynamically reflect actual cost and market prices such as real-time pricing policies (EPPO, 2014).

\section{Identification of Critical Uncertainties}

The drivers identified in 3.2 are prioritized and assessed for their importance and uncertainties. The result is shown in Figure 8.

From Figure 8, drivers with high impact and high uncertainty or so-called "critical uncertainties" are carbon policies, people lifestyle, renewable energy (RE) policies, and renewable energy \& energy storage (RE\&ES) technologies. These four factors are expected to have a critical impact on the direction of Thailand's energy business as they reflect the trends of energy demand and supply as well as the urge to achieve sustainable development goals. Accordingly, they should be taken into account in the development of a national energy roadmap or master plan.

With high impact and low uncertainty, efficiency technologies should be included in energy planning as well. The economic growth may be revisited periodically to observe their impacts on the energy business. Other factors can also be part of the future projection or may be disregarded.

\section{Development of Plausible Scenarios}

The focal issue, drivers, and critical uncertainties identified in the previous steps are used in developing plausible scenarios. 


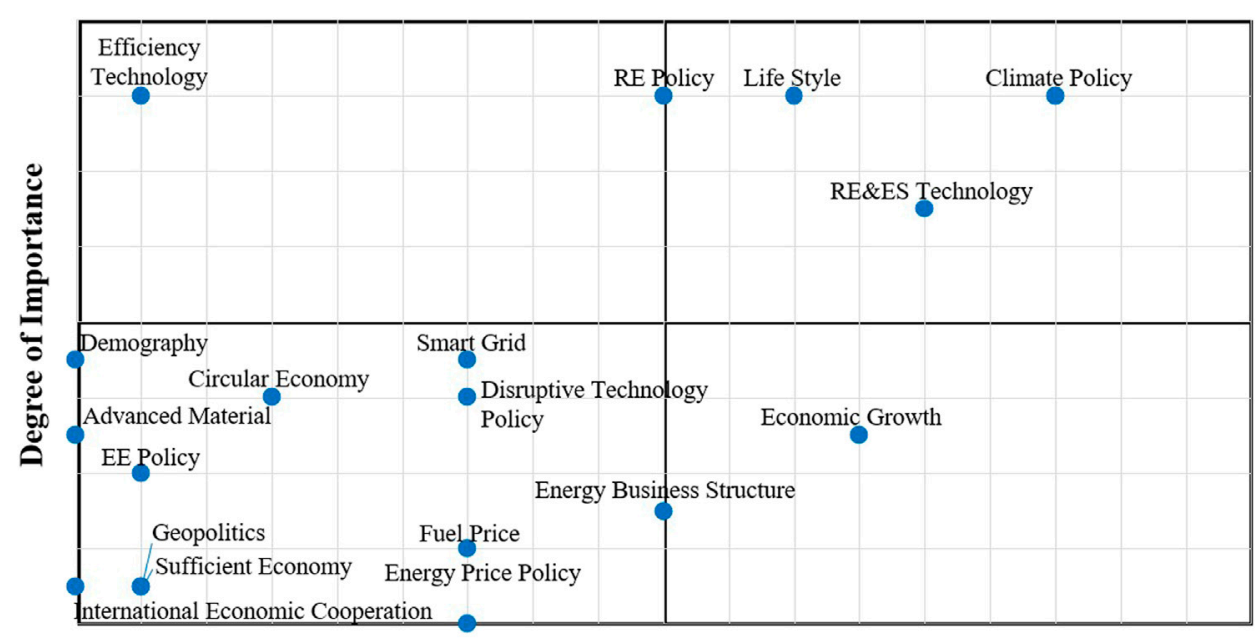

Degree of Uncertainty

FIGURE 8 | Ranking of drivers of Thai energy business towards sustainable development goals.

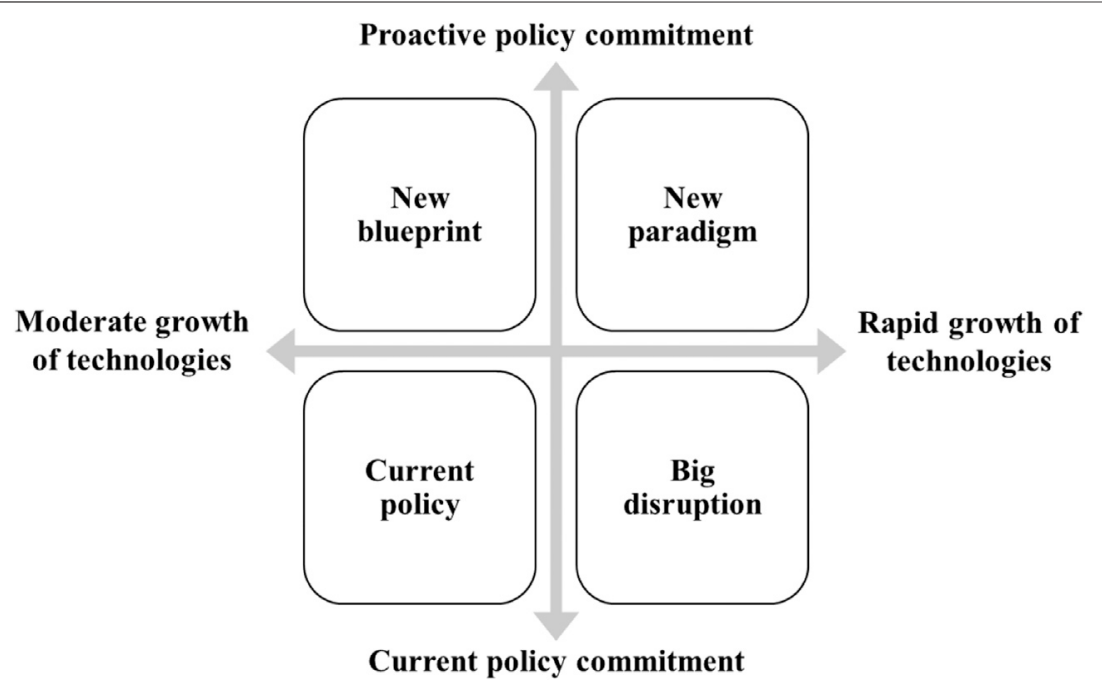

FIGURE 9 | Plausible scenarios of Thai energy business in the next 30 years.

Considering the critical uncertainties, factors that are crucial for Thai energy businesses to achieve sustainable development goals by 2050 can be categorized into two groups. The first group relates to the advancement of technologies especially disruptive technology, renewable energy technology, and an energy storage system. The other group involves policy-driven factors, especially renewable energy policies and climate policies. Both groups will be significant driving forces in changing customer behavior and promoting the adoption of eco-friendly technologies leading to the achievement of sustainable development goals.

Accordingly, four plausible scenarios "to achieve a sustainable development goal (SDG) by 2050" are developed as shown in Figure 9.
Narratives of the four scenarios on the perspective of social, technological, economic, ecological, and political are shown in Table 2.

The above four scenarios indicate different situations, which may occur in the future. They are differentiated by the degree of policy and technology development. The current policy scenario best reflects the most possible view of the Thai energy business. The scenario is developed based on current situations with the consideration of mega-trends as well as changes in economy, society, environment, and technology. The goals of national energy plans are also taken into account based on the current structure of the energy business. It is foreseen that new technologies are unable to hold much of their market share under this scenario. 
TABLE 2 | Narratives of plausible scenarios for Thai energy business toward SDG in 2050.

\begin{tabular}{|c|c|c|}
\hline Perspective & Current policy & Big disruption \\
\hline Social & $\begin{array}{l}\text { People, especially those in urban } \\
\text { areas, will gradually change their life- } \\
\text { style toward a digital lifestyle } \\
\text { Environmental awareness will grow } \\
\text { due to severe pollution problems }\end{array}$ & $\begin{array}{l}\text { People will shift their lifestyles toward } \\
\text { a digital lifestyle with greater environ- } \\
\text { mental awareness and concern, } \\
\text { influenced by the availability of clean } \\
\text { technologies }\end{array}$ \\
\hline Technology & $\begin{array}{l}\text { Clean technology will be adopted by } \\
\text { a limited group of people and cor- } \\
\text { porate social enterprises }\end{array}$ & $\begin{array}{l}\text { Clean technology will be available at } \\
\text { competitive cost. Nevertheless, the } \\
\text { penetration of new technology will } \\
\text { be limited due to regulatory } \\
\text { constraints }\end{array}$ \\
\hline
\end{tabular}

Only distributed photovoltaics (DPV) and electric vehicles (EV) will thrive commercially in the domestic market due to their competitive costs
Economic The national economy will be driven by tourism and export-led industrial production

Petroleum and petrochemical companies will still hold outstanding market capitalization

State enterprises will play a major role in the energy and supply management sectors
Several businesses, particularly petroleum and auto-part industries, will face a risk of digital disruption

Due to the high penetration of DPV \&

EV, state enterprises will face challenges on load management and energy pricing

Environment Pollution from economic activities will still be growing in the long run but at a slower pace due to efficiency and management improvement

The penetration of clean technologies will lessen environmental problems but at a limited capability regulations will become part of the national energy policy without any structural reform implementation

Similar to the current policy scenario, climate change and environmental regulations will become part of the national energy policy without any structural reform implementation
The decoupling of economic growth from pollution generation will be seen before 2050

The SDG and 2DC targets will become part of the national agenda by 2050
People will shift their lifestyles toward a digital lifestyle with greater environmental awareness and concern, influenced by policy incentives and regulations

The growth of clean technology will be driven mainly by government polbe implemented to promote clean

Smart cities with clean energy technologies will be seen in demonstration projects invested by local and central governments

Digitalization will become a major added value for the national economy The energy business will be gradually transformed decentralization towards tions will be limited due to a lack of technology support icy. Direct and indirect incentives will energy technologies

The number of business transforma-

\section{New paradigm}

People will shift their lifestyles toward a digital lifestyle with serious concern for the environment

An eco-system for clean options will be ready for people to make choices Clean and disruptive technologies will be widely adopted in diverse applications throughout daily life

The smart city concept and energy disruptive technologies will be widely adopted in major cities across the country

Integrations of smart energy solutions will be found in the development of business and industry. Examples of such integrations are the integration of DPV with an energy storage system (ESS) and peer-to-peer (P2P) network, and the integration of EV or connected \& automated vehicles (CAV) with vehicle-to-everything (V2X)

Digitalization and clean disruption will contribute significantly to the national economy

Smart and low carbon cities will become the new standard for major cities

The energy business will be completely transformed toward decentralization with the available prosumer business model A market platform will be initiated with the objective to create competition which will lead to efficiency maximization and cost minimization

GHG emission reduction for the wellbelow-2-degrees (2DC) target will be achieved

Both public and business sectors will engage in pollution and waste reduction

The SDG and 2DC targets will become part of the national agenda by 2050 with strong commitments from key stakeholders

Constraints for prosumer and peerto-peer energy trading will be unlocked
Various economic tools will be implemented, e.g., carbon tax and road tax
The big disruption scenario indicates quick market responses to new technologies, while there are no obvious changes or preparedness in business policies and structures. On the other hand, the new blueprint scenario refers to the situation in which significant improvements have been made to energy business policies and structures but there is not much development in emerging technologies.

The new paradigm scenario describes that advanced energy technologies are broadly used and the country has favorable policies to support the development of the energy industry. It 
is, therefore, the most desirable prospect as it best reflects the achievement of sustainable development goals. In this scenario, the energy sector is equipped with innovative technologies including disruptive technologies, advanced renewable energy technologies, and energy storage systems. Additionally, there is policy support stemming from the momentum of climate change agreements and policy structural changes to support the growth of clean energy technologies.

In view of new business potential, a different scenario entails different new business potential depending on policy and technology availability. The new paradigm scenario is expected to offer high market potential with available technologies and policy supports. However, without policy improvement or technology advancement, the business opportunities will be limited to existing technologies.

The developed scenarios can be further used in the development of an energy model, from which the overall national energy balance can be analyzed with detailed sectorby-sector projections. The analysis will provide the correlation of energy consumption, energy supply, and environmental loads. The results will be useful in planning the procurement of clean energy in an appropriate proportion to Thailand 's energy system with a view to achieving the SDGs by 2050 .

\section{CONCLUSION}

Various trends and challenges, both globally and locally, indicate the importance of sustainable development that needs an integrated approach to promote economic growth without compromising environmental protection. Likewise, the energy business should incorporate sustainable development into their corporate vision and strategy in order to successfully thrive in the face of new challenges. In this regard, the study proposes "to achieve sustainable development goals (SDGs) by 2050" as a focal issue for Thailand's energy business.

Among diverse factors, policy and technology are found to be two of the most powerful factors to achieve the goal. Four plausible scenarios derived from these two factors explain the alternative possible situations of Thailand's energy business in the next 30 years. Each of which shows a different context of the energy business according to the level of policy and technology development.

The current policy scenario is the most likely prospect under Thailand's current circumstances. It illustrates that new technologies are still unable to hold much of their market share under existing policies and plans. However, there are also other possible scenarios that deviate from the current policy scenario. The new blueprint scenario reflects the

\section{REFERENCES}

ACerS, AIST, ASM, MRS, TMS. (2010). Advanced materials for our energy future. Compiled by Materials Research Society.

Atkinson, R. D., and Castro, D. D. (2008). Digital quality of life: understand the personal \& social benefits of the information technology revolution, Washington, D.C. government's proactiveness in developing policies to support the SDGs. On the other hand, the big disruption scenario reflects the delay of policy supports, thus is considered to be the least desirable prospect as the national energy management system may not be ready for the disruptive technologies. The new paradigm scenario is the most desirable one as there will be both policies and technology available to support the SDGs. Undoubtedly, business models under the new paradigm scenario will be completely different from the current ones.

Unanswered questions still exist for the energy sector, including how to effectively reallocate capital investments in order to achieve the SDGs under the ongoing energy transition. Therefore, further study on energy modeling is recommended to assess primary and final energy demand as well as the corresponding environmental loads. The results will be useful in the strategic energy planning at both the national and corporate level with a vision to achieve sustainable development goals by 2050 .

\section{DATA AVAILABILITY STATEMENT}

The original contributions presented in the study are included in the article/Supplementary Material, further inquiries can be directed to the corresponding author.

\section{AUTHOR CONTRIBUTIONS}

Conceptualization, WW, JP, and NN; Methodology, WW, JP, and $\mathrm{NN}$; Analysis, WW, JP, and NN; Original draft preparation, NN; Review and editing, NN, WW, and JP; Project administration, $\mathrm{NN}$; All authors have read and agreed to the published version of the manuscript.

\section{FUNDING}

Grants for Development of New Faculty Staff, Ratchadaphiseksomphot Endowment Fund, Chulalongkorn University.

\section{ACKNOWLEDGMENTS}

This paper is an extended and revised article presented at the International Conference on Sustainable Energy and Green Technology 2019 (SEGT 2019) on 11-14 December 2019 in Bangkok, Thailand.

BOI. (2020). Electricity. Accessed October 31, 2020. https://www.boi.go.th/index. php?page=electricity.

Buckley, T., Hipple, K., and Sanzillo, T. (2019). General electric Misread the energy Transition: a cautionary tale. Institute for Energy Economics and Financial Analysis. https://ieefa.org/wp-content/uploads/2019/06/General-ElectricMisread-the-Energy-Transition_June-2019.pdf.

Chaivongvilan, S., Sharm, D., and Sandu, S. (2008). Energy challenges for Thailand: an overview. GMSARN Int. J 2: 53-60. 
Department of Elderly Affairs. (2019). Measures to drive the national Agenda on aging Society (Revised Version). Bangkok: Amarin Printing and Publishing.

EGAT. (2018). EGAT-PEA signs MOU for developing smart grid project in Mae Hong Son Province. https://www.egat.co.th/en/news-announcement/news-release/egatpea-signs-mou-for-developing-smart-grid-project-in-mae-hong-son-province.

EGAT, PEA, MEA. (2016). Infrastructure development plan to support electric vehicles in Thailand. Washington, D.C.: Electricity generating Authority Thailand; Provincial electricity Authority; Metropolitan Electricity Authority.

EIA. (2019). "The effects of changes to marine fuel Sulfur limits in 2020 on energy markets", in Independent Statistics \& analysis. Washington, DC: Energy Information Administration, U.S. Department of Energy, March.

Ellen Macarthur Foundation. (2017). The circular economy in detail. Accessed October 2020. https://www.ellenmacarthurfoundation.org/explore/the-circulareconomy-in-detail.

Enel. (2016). Enel Press Release. Enel. April. https://www.enel.com/content/dam/ enel-common/press/en/1671686-1_PDF-1.pdf.

Energy Regulatory Commission. (2016). Announcement of the energy Regulatory commission regarding the pilot project on the production of solar power on the roof freely.

EnerNOC. (2017). Enel group completes acquisition of leading us-based Provider of Smart energy. Enel X. August 7. https://www.enelx.com/content/dam/enel-xna/press-releases/2017/ENOC_News_2017_8_7_General_Releases_0.pdf.

EPPO. (2014). Annual report 2014. Annual Report. Bangkok: Energy Policy and Planning Office.

EPPO. (2016). Thailand integrated energy blueprint. EPPO Journal special issue. Bangkok: Energy Policy and Planning Office.

EPPO. (2020a). CO2 statistic. http://www.eppo.go.th/index.php/en/en-energystatistics/ co2-statistic.

EPPO. (2020b). Summary statistics. Accessed October 2020. http://www.eppo.go. th/index.php/en/en-energystatistics/summary-statistic?orders[publishUp]= publishUp\&issearch $=1$.

ERC. (2018). Energy regulatory strategy No. 3 (2018-2021). Bangkok: Energy Regulatory Commission.

ERI. (2015). Scaling up solar PV: a roadmap for Thailand. Bangkok: Department of Alternative Energy Development and Efficiency; Chulalongkorn University; British Embassy Bangkok, Energy Research Institute.

ERI. (2020). Scenario analysis and modeling for business strategies. Bangkok: Energy Research Institute.

European Foresight Platform. (2010). Scenario method. Accessed March 2020. http://www.foresight-platform.eu/community/forlearn/how-to-do-foresight/ methods/scenario/.

Farooq, M., Waseem, M., Mazhar, S., and Khairi, A. (2015). A review on Internet of Things (IoT)." Int. J. Comput. Appl. 113, 1-7. doi:10.5120/19787-1571

Garvin, D. A., and Levesque, L. C. (2006). A Note on scenario planning. Boston: Harvard Business School Publishing.

Gilovich, T. (1981). Seeing the past in the present: the effect of associations to familiar events on judgements and decisions. J. Pers. Soc. Psychol. 40, 797-808. doi:10.1037/0022-3514.40.5.797

Government Gazette. (2009). "Ministerial regulation on ministerial regulation prescribing type or size of buildings and their standards", in Criteria and methods for building design for energy conservation, B. E. 2552 B.E., 126. Bangkok.

Grant, R. M. (2003). Strategic planning in a turbulent environment: evidence from the oil majors. Strat. Manag. J. 24: 491-517. doi:10.1002/smj.314

Griffith-Jones, S., Ocampo, J. A., and Spratt, S. (2011). Financing renewable energy in developing countries: mechanisms and Responsibilities. European Report on Development.

Heinrich-Böll-Stiftung. (2020). The coal situation in Thailand and strategic environmental assessment. Accessed October 2020. https://th.boell.org/en/ 2018/05/11/coal-situation-thailand-and-strategic-environmental-assessment.

Hewison, K. (1999). "Thailand's capitalism: the impact of the economic crisis", in UNEAC Asia papers.

Hudson, R., and Heilscher, G. (2012). PV grid integration-system management issues and utility concerns. Energy Proc. 25, 82-92. doi:10.1016/j.egypro.2012.07.012

IEA. (2019). Coal-fired power generation capacity subject to a FID by region (annual average), 2010-2017. December 9. Accessed July 2020. https://www.iea.org/ data-and-statistics/charts/coal-fired-power-generation-capacity-subject-to-afid-by-region-annual-average-2010-2017.

IEA. (2017). Digitalization and energy. Washington, DC: International Energy Agency.
IEA. (2011). OECD green growth studies: energy. Washington, DC: International Energy Agency.

IEA. (2018). World energy outlook 2018. Washington, DC: International Energy Agency. Accessed 2019.

IEA. (2019a). First steps in a reshaping of the energy industry landscape. Accessed June 2020. https://www.iea.org/commentaries/first-steps-in-a-reshaping-ofthe-energy-industry-landscape.

IEA. (2019b). World energy outlook 2019. https://www.iea.org/reports/worldenergy-outlook-2019.

IEA. (2019c). World energy outlook. Paris: International Energy Agency. https:// www.iea.org/reports/world-energy-outlook-2019.

IRENA. (2017). Climate policy drives shift to renewable energy. Paris: International Renewable Energy Agency. Accessed October 2020. https://www.irena.org/-/ media/Files/IRENA/Agency/Topics/Climate-Change/IRENA_Climate_policy_ 2017.pdf.

IRENA. (2020a). Global renewables outlook: energy transformation 2050. Abu Dhabi: International Renewable Energy Agency.

IRENA. (2020b). Innovation landscape brief: Peer-to-peer electricity Trading. Abu Dhabi: International Renewable Energy Agency.

IRENA. (2017). Renewable energy outlook Thailand. Abu Dhabi: International Renewable Energy Agency.

JICA, IDCJ, Pacet. (2013). Data collection survey on housing sector in Thailand, Abu Dhabi: National Housing Authority.

Julian, C. C. (2000). The impact of the Asian economic crisis in Thailand. Manag. Finance 26, 39-48.

Khidhir, S. (2020). Suffocating in Thailand.Accessed October 30, 2020. https:// theaseanpost.com/article/suffocating-thailand.

Kojima, S., and Asakawa, K (2016). Carbon pricing: a key instrument to facilitate low carbon transition. Abu Dhabi: Institute for Global Environmental Strategies.

Liu, Y., Sheng, Z., and Azhgaliyeva, D (2019). Toward energy security in ASEAN: impacts of regional integration, renewables, and energy efficiency. Abu Dhabi: Asian Development Bank Institute.

Ministry of Energy. (2015a). Alternative energy development plan (AEDP2015). Bangkok: Department of Renewable Energy Development and Energy Efficiency.

Ministry of Energy. (2015b). Gas plan 2015. Energy Policy and planning Office. October. http://www.eppo.go.th/images/POLICY/PDF/Gas\%20Plan\%20_Final_Publish.pdf.

Ministry of Energy. (2011). Thailand 20-Year Energy Efficiency Development Plan.

Ministry of Energy. (2018). Thailand power development plan 2018-2037 (PDP2018). Bangkok.

Ministry of Transport. (2017). 4-Year Performance of Ministry of Transport for happiness of Thai People." Bangkok: Ministry of Transport.

MNRE. (2015). Climate change master Plan (2015-2050). Bangkok: Ministry of Natural Resources and Environment.

Nakamura, K., Gu, F., Wasuntarasook, V., Vichiensan, V., and Yoshitsugu, H. (2016). Failure of Transit-oriented development in Bangkok from a quality of life perspective. Asian Transp. Stud. 175, 194-209. doi:10.11175/eastsats. 4.194

Nakano, K., and Honda, K. (2000). Impacts of financial crisis on Asian energy supply and demand and outlook. Accessed October 2020 . https://eneken.ieej. or.jp/data/en/data/old/pdf/e16102.pdf.

Narita, D., Oanh, N. T. K., Sato, K., Huo, M., Permadi, D. A., Chi, N. N. H., et al. (2019). Pollution characteristics and policy actions on fine particulate matter in a growing Asian economy: the case of Bangkok metropolitan Region. Atmosphere 10: 227. doi:10.3390/atmos10050227

National Statistical Office. (2019). Summary of the survey: working conditions of Thai workforce. National Statistical Office. Accessed July 2020 . http://www. nso.go.th/sites/2014/DocLib13/\%E0\%B8\%94\%E0\%B9\%89\%E0\%B8\%B2\%E0\% B8\%99\%E0\%B8\%AA\%E0\%B8\%B1\%E0\%B8\%87\%E0\%B8\%84\%E0\%B8\%A1/\% E0\%B8\%AA\%E0\%B8\%B2\%Е0\%B8\%82\%Е0\%B8\%B2\%Е0\%B9\%81\%Е0\%B8\% A3\%Е0\%B8\%87\%E0\%B8\%87\%E0\%B8\%B2\%E0\%B8\%99/\%Е0\%B8\%A0\%Е0\% $\mathrm{B} 8 \% \mathrm{~B} 2 \% \mathrm{E} 0 \% \mathrm{~B} 8 \% \mathrm{~A} 7 \% \mathrm{E} 0 \% \mathrm{~B} 8 \% \mathrm{~B} 0 \% \mathrm{E} 0 \% \mathrm{~B}$.

National Strategy Secretariat Office. (2018). National Strategy 2018-2037 (Summary). Bangkok: Office of National Economic and Social Development Board.

NESDB. (2011). Clean energy for green low-carbon growth. Thailand: National Economic and Social Development Board.

Neville, K., Baka, J., Gamper-Rabindran, S., Bakker, K., Andreasson, S., Vengosh, A., et al. (2017). Debating unconventional energy: social, political, and 
economic implications. Annu. Rev. Environ. Resour. 42, 611. doi:10.1146/ annurev-environ-102016-061102

Nikomborirak, D. (2017). Chapter 6: SOE Reform in Thailand: preparing for free trade agreements. Thailand Development Research Institute, Bangkok: JETRO Bangkok/ IDE-JETRO.

Office of the Council of State. (2007). Energy conservation Act B.E.2535 (amended)

ONEP. (2015). Thailand's intended nationally determined contribution (INDC). Bangkok: Office of natural resources and environmental policy and planning. https://www4.unfccc.int/sites/ndcstaging/PublishedDocuments/Thailand\% 20First/Thailand_INDC.pdf.

Panya, O., and Sirisai, S. (2003). Environmental conciousness in Thailand: contesting maps of eco-conscious minds. South East Asian Stud. 41 (1), 410. https://kyoto-seas.org/pdf/41/1/410105.pdf.

Pasaoglu, G., Fiorello, D., Zani, L., Martino, A., Zubaryeva, A., and Thiel, C. (2013). "Projections for electric Vehicle load profiles in Europe based on travel Survey data", in JRC Scientific and policy Reports, European Commission; Joint Research Centre; Institute for Institute for Energy and Transport, Milan: Joint Research Centre of the European Commission. doi:10.2790/24108

Perez, J. A., Deligianni, F., Ravi, D., and Yang, G. (2017). Artificial intelligence and robotics.

PESTLEAnalysis.com. (2015). What is STEEP Analysis? https://pestleanalysis. com/what-is-steep-analysis/.

Proctor, D. (2017). GE Cutting 12,000 Jobs in Power Division. December 7. https:// www.powermag.com/ge-cutting-12000-jobs-in-power-division/.

Qin, Z., Shundong, L., Yi, H., Jinchun, D., Lixiang, Y., and Jun, Q. (2009). “Security technologies in E-commerce.” in Introduction to E-commerce, edited by Qin, Z. Berlin: Springer. doi:10.1007/978-3-540-49645-8_4

Rastogi, V. (2018). Thailand's E-commerce landscape: trends and opportunities. Dezan Shira \& Associates.

Rhydderch, A. (2017). "Scenario building: The 2x2 matrix Technique." Edited by K. Radford Futuribles International.

Rialland, A., and Wold, K. E. (2020). "Future Studies, foresight and Scenarios as basis for better Strategic decisions." in IGLO-MP2020 Working Paper No. 102009. 2009 innovation in global maritime production 2020 project. http://www. forschungsnetzwerk.at/downloadpub/IGLO_WP2009-10_Scenarios.pdf.

Richter, M. (2013). German utilities and distributed PV: how to overcome barriers to business model innovation renewable energy. Renew. Energy 55, 456-466.

Rizos, V., Tuokko, K., and Behrens, A. (2017). "The circular economy: a review of definition, process and impacts." in CEPS Research Report No. 2017/8, Centre for European Policy Studies, Brussels. Accessed October 2020 . http://aei.pitt. edu/85892/1/RR2017-08CircularEconomy0.pdf.

Schoemaker, P. J. H. (1993). Multiple scenario development: its conceptual and behavioral foundation. Strat. Manag. J 14, 193-213.

Schwartz, P. (1996). The Art of teh long view: planning for the future in an uncertain World. New York: Doubleday.

Seba, T. (2014). Clean disruption of energy and transportation: How Silicon valley make oil, Nuclear, natural gas, and coal obsolete by 2030. California.

Shell International BV (2018). Sky scenarios: meeting the goals of the Paris agreement. Accessed 2019. www.shell.com/skyscenario.

Shell. (2020). Shell scenarios. https://www.shell.com/energy-and-innovation/theenergy-future/scenarios.html.
Silvestre, M. L. D., Favuzza, S., Sanseverino, E. R., and Zizzo, G. (2018). How decarbonization, digitalization and decentralization are changing key Power infrastructures. Renew. Sustain. Energy Rev. 18, 371.

Suthiwong, R. (2017). Renewable energy for national Security. Bangkok: National Defence College of Thailand.

Sutthasri, P., Phongluengthum, W., and Charoonpipatkul, N. (2019). Sharing economy: implications for Thai economy. Bangkok: Bank of Thailand.

TDRI. (2018). Reorienting the Thai economy to prepare for the age of technological disruptions. Accessed October 18, 2020. https://tdri.or.th/en/2018/05/annualcon-2018-news/.

Thai Oil. (2020). Presentation to investors. Thai oil public company limited. Accessed October 2020. https://investor.thaioilgroup.com/misc/PRESN/20200330top-MonthlyPresentation-202003.pdf.

The Chaipattana Foundation. (2017). Philosophy of Sufficiency economy. Accessed July 2020. https://www.chaipat.or.th/eng/concepts-theories/sufficiency-economynew-theory.html.

Thongplew, N., Spaargaren, G., and Koppen, K. V. (2017). Companies in search of the ggreen consumer: sustainable consumption and production strategies of companies and intermediary organizations in Thailand. NJAS Wageningen J. life Sci 17, 12-21.

Tundele, S. (2015). Eco-friendly technology - key for sustainable development. Int. J. Res. Granthaalayah 3, 371.

UNDP. (2020). Sustainable development goals. https://www.undp.org/content/ undp/en/home/sustainable-development-goals.html.

Vapattanawong, P., and Prasartkul, P. (2005). Future Thai population. http://www. ipsr.mahidol.ac.th/IPSR/AnnualConference/ConferenceII/Article/Article02.htm.

Virk, A., Noor, M. A., Fiaz, S., Hussain, S., Hussain, H., Sen, M., et al. (2020). Smart farming: an overview." in Smart village technology: concepts and developments, edited by S. Patnaik, S. Sen, and M.S. Mahmoud, New York: Springer, 191-201. doi:10.1007/978-3-030-37794-6_10

Wautelet, T. (2018). The concept of circular economy: its origins and its evolution. doi:10.13140/RG.2.2.17021.87523

World Bank. (2019). World Bank national accounts data.

World Economic Forum. (2019). The global Risks Report 2019 (14th Edition). Geneva: World Economic Forum. http://www3.weforum.org/docs/WEF_ Global_Risks_Report_2019.pdf.

Yeager, K., Dayo, F., Fisher, B., FouquetGilau, A., Rogner, H., et al. (2012). Energy and economy." in Global energy assessment: toward a sustainable future, edited by N. Lustig, Cambridge: Cambridge University Press, 385-422.

Conflict of Interest: The authors declare that the research was conducted in the absence of any commercial or financial relationships that could be construed as a potential conflict of interest.

Copyright (C) 2021 Nakapreecha, Pongthanaisawan and Wangjiraniran. This is an open-access article distributed under the terms of the Creative Commons Attribution License (CC BY). The use, distribution or reproduction in other forums is permitted, provided the original author(s) and the copyright owner(s) are credited and that the original publication in this journal is cited, in accordance with accepted academic practice. No use, distribution or reproduction is permitted which does not comply with these terms. 